\title{
the review of
}

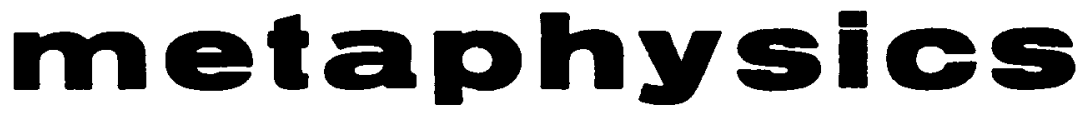

a philosophical quarterly

\section{ISSN $0034-6632$}

DECEMBER 1990 | VOL. XLIV, No. 2 | ISSUE No. 174 | \$10.00

\author{
articles
}

books received

philosophical abstracts

announcements

gaN-cARLO ROTA

EDWARD G. SPARROW

ALBERT SHALOM

PAUL WEISS

KENNETH DORTER

WOOSUK PARK
MARK M. HURLEY AND STAFF

Mathematics and Philosophy: The Story of a Misunderstanding Erasing and Redrawing the Number Line: An Exercise in Rationality Temporality and the Concept of Being On the Impossibility of Artificial Intelligence Levels of Knowledge in the Theaetetus Haecceitas and the Bare Particular Summaries and Comments philosophical abstracts announcements

Individual Subscriptions $\$ 23.00$ Institutional Subscriptions $\$ 40.00$

Student/Retired Subscriptions $\$ 12.00$ Jude P. Dougherty, Editor

The Catholic University of America. Washington, D.C. 20064 


\section{PHILOSOPHICAL INVESTIGATIONS}

\section{Edited by D Z Phillips}

\section{Philosophical Investigations} has developed a tradition of publishing scholarly and thought-provoking articles in all branches of philosophy.

These articles are complemented by a Discussion section and an extensive Book Review section. Special issues are occasionally published.
Recent articles include:

Essay on the Notion of Reading Simone Weil

An Anti-Sceptical Fugue

Grant Gillett

The Idea of Transcendence

Robert C Coburn

Working with Wittgenstein's

Builders

Douglas Birsch and

Jon Dorbolo

\section{ORDER FORM}

Subscription Rates, Volume 14, 1991

Individuals $\$ 24.00$ (UK), 227.50 (Europo), $\$ 54.50$ (N Amorica), $\$ 30.00$ (Rest of World) Institutions ع58.00 (UK), $\mathbf{8 6 2 . 0 0}$ (Europo), $\$ 133.50$ (N Amorica), $\mathbf{E 7 3 . 5 0}$ (Rest of World) Published quarterly
$\square \quad$ Please enter my subscription/send me a sample copy
$\square \quad$ I enclose a cheque/money order made payable to Basil Blackwell
$\square \quad$ Please charge my Access/American Express/Diners Club/ MastercardNisa account number

For payments via the National Girobank, the Basil Blackwell account number is 2366053 Name

Address

Postcode

Signature Date

Payment must accompany orders

Please return this form to: Journals Marketing Manager, Basil Blackwell, 108 Cowley Road, Oxford OX41JF, England. Rogistered No. 180277. Or to: Journals Marketing Manager, Basil Blackwell, Three Cambridge Center, Cambridge, MA 02142, USA 


\section{Cambridge}

\section{Sources of the Self}

The Making of the Modern Identity

CHARLES TAYLOR

Charles Taylor's latest book sets out to define the modern identity by tracing its genesis.

This definition is then taken as the starting point for a renewed understanding of modernity.

'Sources of the Self' is in every sense a large book . . . in the generosity and breadth of its sympathies and its interest in humanity.'

New York Review of Books $£ 32.50$ net HB $0521383315 \quad 608$ pp.

\section{Now in paperback}

\section{Hegel}

Religion, Economics and the Politics of Spirit 1770-1807

\section{LAURENCE DICKEY}

'The scholarship with which Dickey presents his case is remarkable for both its depth and its range ... His book is a remarkable one and will prove indispensable to Hegel specialists, but also of great interest to historians of ideas in general.'

Michael Inwood, The Times Literary Supplement

f13.95 net PB $0521389127 \quad 480$ pp.

Ideas in Context

\section{Critique and Construction}

A Symposium on Roberto Unger's Politics

Edited by ROBIN W. LOVIN and MICHAEL PERRY

The publication of Robert Mangabeira Unger's provocative and controversial work Politics (CUP, 1988) was a major event for political and social theorists. This volume contains essays on Unger's work by a wide range of social, political and legal theorists. $£ 32.50$ net $\mathrm{HB} \quad 0521352088 \quad 344 \mathrm{pP}$.

\section{Now in paperback}

\section{Rethinking Democracy}

Freedom and Social Cooperation in Politics, Economy and Society

\section{CAROL C. GOULD}

In this book Carol Gould offers a fundamental reconsideration of the theory of democracy, arguing that democratic decision-making should apply not only to politics but also to economic and social life.

'A more impartial and fair-minded advocate it would be hard to find.'

Maurice Cranston, The Times Literary Supplement f11.95 net PB 0521386292376 pp.

\section{The Philosophy in Christianity}

\section{Edited by GODFREY VESEY}

This important collection examines the central doctrines of Christianity and the ways in which, in the formulation of these doctrines, Christians have drawn on philosophical ideas.

£10.95 net HB $0521375789300 \mathrm{pp}$.

Royal Institute of Philosophy Lectures 25

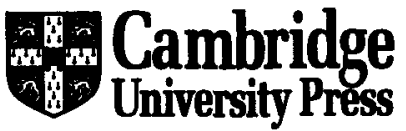

The Edinburgh Building, Cambridge CB2 2RU, UK. 


\section{Cambridge}

\section{Deciding for Others}

The Ethics of Surrogate Decision-making

\section{ALLEN BUCHANAN and DAN W. BROCK}

This book is the most comprehensive treatment available of one of the most urgent and in some respects most neglected - problems in bioethics: decision-making for incompetents. The authors' approach combines a probing analysis of fundamental issues in ethical theory with a sensitive awareness of the concrete realities of health care institutions and the highly personal and individual character of difficult practical problems. £32.50 net HB $052132422 \times \quad 440 \mathrm{pp}$

f11.95 net PB 0521311969

Studies in Philosophy and Health Policy

\section{Now in paperback}

\section{Hard Choices}

Decision Making Under Unresolved Conflict

\section{ISAAC LEVI}

In this account of rational decision-making, Isaac Levi argues that agents should often choose between competing values without having balanced those values and that rationality does not require that an act be optimal, only that it be what Levi terms 'admissible'.

f10.95 net HB $0521386306 \quad 272$ pp.

\section{On Action}

\section{CARL GINET}

This book deals with foundational issues in the theory of the nature of action, the intentionality of action, the compatibility of freedom of action with determinism, and the explanation of action. By demonstrating that every action has as its core a 'simple' mental action, Ginet develops a sophisticated account of the individuation of actions. $£ 25.00$ net HB $052138124 X$ £9.50 net PB $052138818 X$ Cambridge Studies in Philosophy

\section{Rationality in Action}

\section{Contemporary Approaches}

Edited by PAUL K. MOSER

This anthology includes twenty-one selections falling under three main categories: individual decision theory; game theory and group decision-making; reasons, desires and intentionality.

f40.00 net HB $0521385725 \quad 450 \mathrm{pp}$. f14.95 net $P B \quad 0521385989$

\section{A Combinatorial Theory of Possibility}

\section{M. ARMSTRONG}

Taking Wittgenstein's Tractatus as his point of departure, Professor Armstrong argues that nonactual possibilities and possible worlds are recombinations of actually existing elements, and as such are useful fictions.

E25.00 net HB $0521374278 \quad 176$ pp.

$€ 8.50$ net $P B \quad 0521377803$

Cambridge Studies in Philosophy

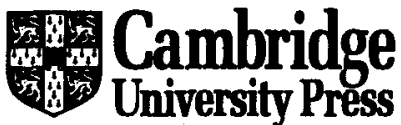

The Edinburgh Building, Cambridge CB2 2RU, UK. 


\section{Cambridge}

\section{The Sophismata of Richard Kilvington}

Translated by NORMAN KRETZMANN and BARBARA ENSIGN KRETZMANN

Richard Kilvington was an obscure fourteenth-century philosopher whose Sophismata deal with a series of logic-linguistics conundrums of a sort which featured extensively in philosophical discussions of the period. This is the first ever translation of his work and is accompanied by a detailed commentary.

f32.50 net HB $0521354196 \quad 450 \mathrm{pp}$.

\section{The Mundane Matter of the Mental Language}

\section{J. CHRISTOPHER MALONEY}

Christopher Maloney offers an explanation of the fundamental nature of thought by positing the idea that thinking involves the processing of mental representations that take the form of sentences in a covert language encoded in the mind.

f29.95 net HB $0521370310 \quad 350 \mathrm{pp}$.

Cambridge Studies in Philosophy

\section{A Theory of Property \\ STEPHEN R. MUNZER}

In this book, Stephen R. Munzer argues for the justification of some rights of private property while showing why unequal distributions of private property are indefensible. The book represents a major new statement on the issue of property rights.

f37.50 net HB $0521372844512 \mathrm{pp}$.

f13.95 net PB 0521378869

\section{Systems of Logic}

\section{NORMAN M. MARTIN}

This is an advanced study of systems of propositional logic which offers a comprehensive account of a wide variety of logical systems and which encourages students to take a critical stance on the subject.

f30.00 net HB 0521365899320 pp.

f11.95 net PB 0521367700

\section{Computability and Logic}

\section{Third Edition}

\section{GEORGE S. BOOLOS and RICHARD C. JEFFREY}

A text for second course in logic for graduate and advanced undergraduate students. This third edition has been corrected and contains thoroughly revised versions of the chapters on Ramsey and provability, with new exercises provided for three other chapters.

£37.50 net HB $052138026 \times \quad 316$ pp.

£13.95 net PB 0521389232

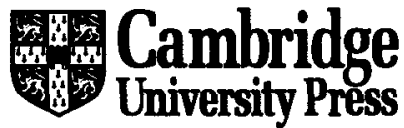

The Edinburgh Building, Cambridge CB2 2RU, UK. 


\section{CAMBRIDGE TEXTS IN THE}

\section{HISTORY OF POLITICAL THOUGHT}

Eight new titles in this major textbook series

Making available to students and teachers the most important texts in the history of political thought.

Hobbes: Leviathan Edited by RICHARD TUCK

£27.50 net HB 0521394929 £6.95 net PB 0521396417 560 pp.

\section{Cicero: On Duties}

Edited by MIRIAM GRIFFIN and MARGARET ATKINS

£19.50 net HB 0521343380 £6.95 net PB 0521348358 $200 \mathrm{pp}$.

Bakunin: Statism and Anarchy

Edited by MARSHALL SHATZ £27.50 net HB 0521361826 f9.95 net PB 0521369738 $288 \mathrm{pp}$.

John of Salisbury: Policraticus

Edited by CARY J. NEDERMAN £27.50 net HB 0521363993 £9.95 net PB 0521367018 264 pp.
Kant: Political Writings Edited by H. S. REISS

Translated by H. B. NISBET

£27.50 net HB 0521391857 £9.95 net PB 0521398371 320 pp.

\section{Milton: Political Writings} Edited by MARTIN DZELZAINIS Translated by CLAIRE GRUZELIER $£ 27.50$ net HB 0521343941 f9.95 net PB 0521348668 304 pp.

Filmer: Patriarcha and Other Writings

Edited by JOHANN P. SOMMERVILLE

£27.50 net HB $052137491 X$ f9.95 net PB 0521399033 $368 \mathrm{pp}$.

Bossuet: Politics Drawn From the Very Words of Holy Scripture Edited by PATRICK RILEY £40.00 net HB 0521362377 $544 \mathrm{pp}$.

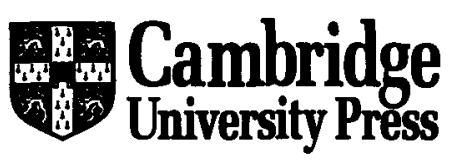

The Edinburgh Building, Cambridge CB2 2RU, UK. 


\section{Proceedings of the Annual Conferences of the U.K. Association for Legal and Social Philosophy in the series Archiv für Rechts- und Sozialphilosophie. Beihefte}

36. Richard Bellamy, ed.: Liberalism and Recent Legal and Social Philosophy Fifteenth Conference, 7th-9th April, 1988. 1989. 126 pages. Kart. DM 44,With contributions by: J. Bell, R. Bellamy, R. Brownsword, C. Coope, S. Guest, P. Jones, S. Mendus, A. Ryan, M. Stokes

34. Robert N. Moles, ed.: Law and Economics Fourteenth Conference, 2nd-4th April, 1987. 1988. 134 pages. Kart. DM40,With contributions by: R. N. Moles, A. Ogus, R. Harrison, J. Williams, J. Moreh, A. Hunt, S. Leader, H. Collins, R. Shiner, J. L. Gorman, C. McCarthy

32. Mark Ockelton, ed.: Medicine, Ethics and Law

Thirteenth Conference, 4th-6th April, 1986. 1987.111 pages. Kart. DM 36,With contributions by: D. D. Raphael, J. Jackson, R. D. MacKay, E. F. Kingdom, A. Samuels, A. T. H. Smith, J. Cottingham, R. G. Lee, J. Harris

28. Gerry Maher, ed.: Freedom of Speech: Basis and Limits Twelfth Conference 29th-31st March, 1985. 1986. 88 pages. Kart. DM 28,With contributions by: R. A. Shiner, R. Bellamy, S. S. Kleinberg, A. J. M. Milne, T. C. Gibbons, D. J. Goldberg, D. Galbraith, S. A. Wolfson

21. Stephen Guest/Alan Milne, eds.: Equality and Discrimination: Essays in Freedom and Justice Eleventh Conference, 6th-8th April, 1984. 1985. 102 pages. Kart. DM 38,With contributions by: S. Guest, J. Waldron, K. O'Donovan, S. Marshall, C. McCrudden, A. Sen, B. Williams, H. Steiner, P. Day, P. Ingram

19. Antony Duff / Nigel Simmonds, eds.: Philosophy and the Criminal Law Tenth Conference, 8th-10th April, 1983. 1984. 120 pages. Kart. DM 38,With contributions by: N. Simmonds, T. Eckhoff, N. Lacey, A. Duff, M. Wasik, H. Gross, T. Honderich, A. Ashworth, J. Harris, G. Maher, J. Cottingham

16. William Twining, ed.: Facts in Law

Ninth Conference, 2nd-4th April, 1982. 1983. IX, 157 pages. Kart. DM 48,With contributions by: L. J. Cohen, R. Eggleston, G. J. Postema, W. Twining, J. D. Jackson, M. Ockelton, A. R. White, R. S. Summers, D. Holcroft, A. Zuckerman

\section{Franz Steiner Verlag Stuttgart}

Postfach 101526 - D - 7000 Stuttgart 10 


\title{
REVUE INTERNATIONALE DE PHILOSOPHIE
}

\author{
Editor : Michel MEYER
}

\author{
143, av. A. Buyl, 1050 Brussels, Belgium
}

Each number is devoted to a particular movement, a particular philosopher, or a particular problem.

We publish 4 issues annually. Articles are written in English, French, German, or Italian.

Our last issue was devoted to Foucault

Articles by : A. Kremer-Marietti, Présentation - M. Foucault, La psychologie de 1850 à 1950 - D. Huisman, Note sur l'article de Michel Foucault - S. Delivoyatsis, Le pouvoir de la différence - P. Major-Poetzl, The Disorder of Things - H. L. Dreyfus, Foucault et la psychothérapie - K Racevskis, The Conative Function of the Other in Les Mots et les Choses - A. KremerMarietti, De la matérialité du discours saisi dans l'institution - J.-M. Auzias, Les gisants et les pleureuses. Pour un tombeau de Michel Foucault - Analysis and reviews.

Coming numbers : Le Questionnement - Critique du jugement (I and II) Bergson 


\section{THE PHILOSOPHICAL QUARTERLY}

Edited by Neil Cooper

Founded in 1950, The

Philosophical Quarterly is one of the best-established journals in its field. The journal aims to foster and publish significant contributions in every branch of the subject, promoting discussion of recent philosophical work and providing critical reviews of recent books.
Recent and Forthcoming

Articles include: Expressions of Passage Gilbert Plummer Whose Language Is It Anyway? Alexander George Why Content Must Be A Matter of Truth Conditions Angus Ross Posthumous Harm Dorothy Grover

\section{ORDER FORM}

Subscription Rates, Volumo 40, 1990

Individuals E14.00 (UK), E17.00 (Europe), $\$ 22.00$ (N America), E17.50 (overseas) Institutions 237.00 (UK), 847.00 (Europe), $\$ 83.00$ (N Anverica), E50.00 (overease) Published January, April, July and October

$\square \quad$ Please enter my subscription/send me a sample copy

․ I enclose a cheque/money order made payable to Basil Blackwell

P Please charge my Access/American Express/Barclaycard/Diners Club/Mastercard/Visa account number

Expiry Date

For payments via the National Girobank, the Basil Blackwoll acoount number is 2366053 Name

Address

Signature Date

Payment must accompany orders

Please return this form to: Journals Marketing Manager, Basil Blackwell, 108 Cowley Road, Oxford OX41JF, England or to: Journals Markoting Manager, Basil Blackwoll, Three Cambridge Center, Cambridge, MA 02142, USA 


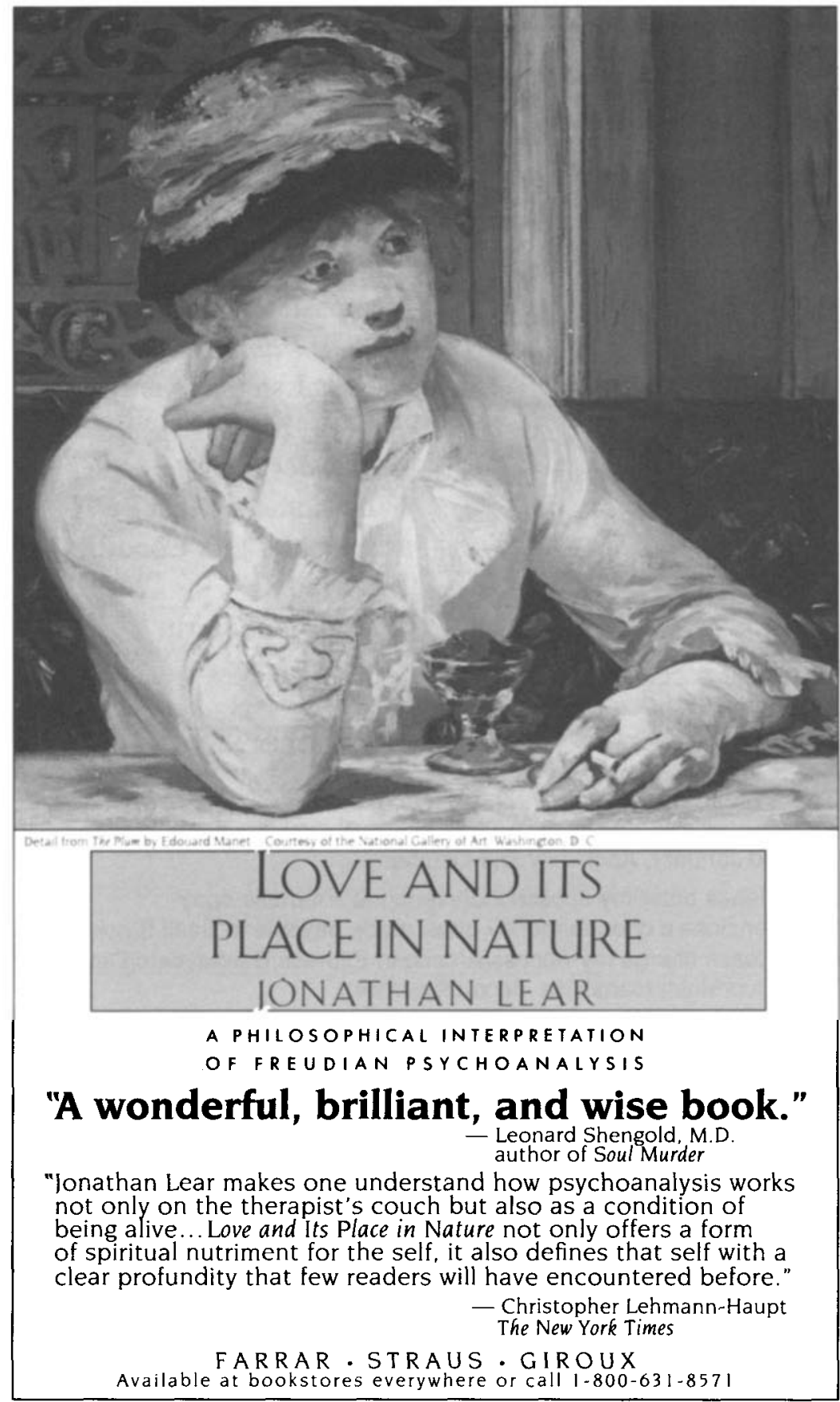




\section{Information for Authors}

Prospective authors should send their contributions, typed and double-spaced on quarto or A4 paper, to the Editor, Mr Renford Bambrough, Royal Institute of Philosophy, 14 Gordon Square, London WC1H 0AG. They should retain a second copy for the purpose of checking proofs. Articles submitted should conform to Hart's Rules for Compositors and Readers (Oxford University Press, 1967). The Editor may alter manuscripts wherever necessary to make them conform to the stylistic and bibliographical conventions of the journal. Single quotation marks should be used except where there is a quotation within another. The titles of books and journals should be underlined (i.e. to be printed in italics), as should foreign words. Titles of articles should be in single quotation marks.

Notes and references will be printed as footnotes and should be typed (double-spacing) on a separate sheet, numbered consecutively. They should be referred to in the text by superscripts. Citations should be as follows:

${ }^{1}$ H. B. Acton, The Philosophy of Punishment (London: Macmillan, 1969), 192-198.

${ }^{2}$ R. S. Downie and Elizabeth 'Telfer, 'Autonomy', Philosophy 46, No. 178 (October 1971), 295.

${ }^{3} \mathrm{Op}$. cit. note $1,101-112$.

${ }^{4}$ W. C. Wimsatt, 'Some Problems with the Concept of Feedback', Boston Studies in the Philosophy of Science, VIII, R. C. Buck and R. S. Cohen (eds.) (Dordrecht: D. Reidel, 1971), 242.

The return of contributions cannot be guaranteed unless they are accompanied by stamps, or in the case of contributions from abroad, by international coupons, to cover postage. A self-addressed envelope should also be enclosed.

Only corrections of printer's errors can be allowed in proofs. Authors are therefore asked to send any alterations or additions to Mr Bambrough as soon as possible after receiving his letter of acceptance.

Authors of articles, discussion papers and review articles will receive twenty-five offprints free of charge. Additional offprints can be ordered when proofs are returned by arrangement with the Institute.

Books for review should be sent to the Editor at the Institute and not to Cambridge University Press. Publishers are asked to note that nonphilosophical works are not reviewed in Philosophy.

Authors' corrected proofs should be sent to Mr Bambrough at St John's College, Cambridge. All other correspondence should be addressed to the Institute and not to any address in Cambridge. 


\section{Philosophy}

VOLUME 66 NO 256 APRIL 1991

Editorial: Penny Bundles

Socrates' Critique of Cognitivism - WALLACE 1. MATSON and ADAM LEITE

The Art of Philosophy - NEIL COOPER

Capital Punishment and Realism - DAVID COCKBURN

The Neurophilosophy of Pain-G. R. GiLlett

Kant's Psychological Hedonism-A. PHILLIPS GRIFFITHS

Sachererhalt and Gegenstand are Dead-E. F. Tном Pк1NS

Discussion

Knowing Good and Evil - C. J. F. WILlıams

Not Over Yet: Prior's 'Thank Goodness' Argument KIERNAN DELMAS-LEWIS

Cohen on Einstein's Simultaneity Gedankenexperiment v. ALAN WHITE

New Books

Reviews

Booknotes

Books Received

Notebook

(C) The Royal Institute of Philosophy 1991

\section{CAMBRIDGE UNIVERSITY PRESS}

The Pitt Building, Trumpington Street, Cambridge CB2 1RP

40 West 20th Street, New York, NY 10011-4211, USA

10 Stamford Road, Oakleigh, Melbourne 3166, Australia 